\title{
Phytoaccumulation of Copper from Aqueous Solutions Using Eichhornia Crassipes and Centella Asiatica
}

\author{
Hamizah Mokhtar, Norhashimah Morad, Fera Fizani Ahmad Fizri
}

\begin{abstract}
Phytoremediation is a relatively new approach to treat wastewater contaminated by organic and inorganic substances including heavy metals. The effectiveness of two aquatic plants, Centella asiatica and Eichhornia crassipes, were evaluated for their capabilities in removing copper from copper solution. The aim of this study is to determine the potential of these aquatic plants to act as hyperaccumulators. The aquatic plants were put in 8 liters of solution containing $1.5 \mathrm{mg} / \mathrm{L}, 2.5$ $\mathrm{mg} / \mathrm{L}$ and $5.5 \mathrm{mg} / \mathrm{L}$ of copper, for a period of 21 days. Analyses of heavy metals contents were conducted using an Atomic Adsorption Spectrometer. Results showed an increase of copper within the plants' roots and shoots tissues and a decrease of copper concentration in the solution. The maximum removal of copper in the solutions containing Centella asiatica was $99.6 \%$ as compared to $97.3 \%$ in solutions containing Eichhornia crassipes. Centella asiatica accumulated a maximum amount of copper of $1353.0 \mathrm{mg} / \mathrm{kg}$ whereas Eichhornia crassipes accumulated $1147.5 \mathrm{mg} / \mathrm{kg}$ of copper in their roots. The accumulation of copper of more than $1000 \mathrm{mg} / \mathrm{L}$ in plant tissues indicate that both aquatic plants can be considered as hyperaccumulators of copper. Roots tend to accumulate a higher amount of copper than shoots due to translocation process. Significant removal of copper were obtained at $\mathbf{p}<0.01$ for containers containing both aquatic plants, indicating that Centella asiatica and Eichhornia crassipes can be utilized in the phytoremediation method to remove copper from wastewater.
\end{abstract}

Index Terms- Centella asiatica, Copper, Eichhornia crassipes, Phytoaccumulation

\section{INTRODUCTION}

The rapid pace of industrialization and urbanization activities has become a major environmental concern due to dispersal of wastes generated on the ecosystem. Heavy metals are one of the most hazardous contaminants that may be present in the aquatic ecosystem. Heavy metals are elements having an atomic weight between 63.54 and 200.59 and a specific gravity greater than 4 [1]. These heavy metals are highly toxic to the aquatic biodiversity, and drinking contaminated water containing heavy metal poses severe health hazards in humans. According to the World Health

Manuscript received May 26, 2011. The authors gratefully acknowledge financial support from Institute of Postgraduate Studies, Universiti Sains Malaysia in the form of the postgraduate fellowship provided to the first author.

H. Mokhtar is an MSc student in the Environmental Technology Division, School of Industrial Technology, Universiti Sains Malaysia. (e-mail: ami_872001@yahoo.com).

N. Morad is with the Environmental Technology Division, School of Industrial Technology, Universiti Sains Malaysia, 11800 Penang, Malaysia. (e-mail: nhashima@usm.my).

F.F. Ahmad Fizri is with the Environmental Technology Division, Universiti Sains Malaysia (e-mail: fera@usm.my).
Organization (WHO) (1984), the most immediate concern and abundant metals are cadmium, chromium, copper, lead, nickel, and zinc. Copper is an essential micronutrient to the plants but at higher concentrations they may become toxic [2]. Contaminations of copper, nickel and zinc are normally due to release from a variety of sources including electroplating, mining, urban sewage, smelters, tanneries, textile industry and chemical industries [2]. Nickel may cause skin rashes, asthma and cancer whereas copper and zinc can lead to kidney and liver disfunction. According to Ministry of Health Malaysia, the limit for drinking water quality is $0.01 \mathrm{mg} / \mathrm{L}$ for copper. The industrial effluent discharge standard (Std A) for Malaysian inland waters is $0.2 \mathrm{mg} / \mathrm{L}$ for copper, according to the Environmental Quality Act, 1974 with latest amendment in 2009. Even though the industries may employ treatment systems to treat their effluents, sudden changes in their manufacturing processes or breakdown of wastewater equipment may cause wastewater containing heavy metals that exceed the discharge limits to be inadvertently released into the environment. Various methods have been employed to clean-up the effluents. These methods include ion-exchange, chemical precipitation and disinfection, adsorption by activated carbons, reverse osmosis and nanofiltration. Most of these methods are expensive, require high energy and are not able to completely remove the heavy metals [3]. Contrary to this conventional method, phytoremediation, i.e. the use of trees of plants to remediate contaminated soil or water, is a relatively new approach which is considered more cost-effective and environment-friendly. The future of phytoremediation is still in the development phase and many hyperaccumulator plants with the capability to remove heavy metals remain to be discovered. The major benefits of using aquatic plant-based treatment system are that they require a small amount of energy, the system is completely natural and the plants easily regenerate [4]. Plants can help to remediate heavy metal contaminated soil or water through several mechanisms namely rhizofiltration, phytostabilization, phytoextraction, phytotransformation, phytovolatilization, and phytodegradation [1].

Several plants species, such as water lettuce (Pistia stratiotes), duckweed (Spirodela polyrrhiza), parrot feather (Myriophylhum aquaticum), creeping primrose (Ludwigina palustris), watermint (Mentha aquatic), and water lilies (Nymphaea spontanea) have been studied to determine their potential in accumulating heavy metals [3],[5],[6]. Among the various plant species, aquatic macrophytes attain the greatest interest in the field of phytoremediation. Aquatic macrophytes have great potential to accumulate heavy metals inside the plant bodies. These plants can accumulate heavy 
metals up to 100,000 times greater than the amount in the associated water [4]. Therefore, these macrophytes have been used for heavy metal removal from a variety of sources. Aquatic macrophytes such as water hyacinth, is one of the most commonly used plants in constructed wetlands because of its fast growth rate and large uptake of nutrients and contaminants [2]. Water lettuce, water zinnia and fuzzy water clove have also been shown to be effective in removing trace elements from water and accumulate them in their bodies [7].

In this study, two aquatic plants, water hyacinth (Eichhornia crassipes) and pennywort or 'pegaga' in Malay (Centella asiatica), were used to determine their potential in removing copper of various concentrations from copper solutions. Eichhornia crassipes and Centella asiatica are two of the most abundant aquatic plants in Malaysia and have been found to thrive in canals, rivers and man-made lakes. The effectiveness of the plants in removing copper from the solution as well as the potential of the plants to accumulate copper were determined based on copper content analyses in the solution, roots and shoots of the plants.

\section{Materials And Methods}

\section{A. Plants Material}

Eichhornia crassipes and Centella asiatica were collected from Harapan Lake, at Universiti Sains Malaysia, Penang. These aquatic plants were put in a hydroponic system containing tap water, for a two-week acclimatization period, before being exposed to heavy metal contaminants.

\section{B. Preparation of copper contaminated solution}

Synthetic solution of copper at $1.5 \mathrm{mg} / \mathrm{L}, 2.5 \mathrm{mg} / \mathrm{L}$ and 5.5 $\mathrm{mg} / \mathrm{L}$ concentration were prepared using the copper standard solution of $1000 \mathrm{mg} / \mathrm{L}$ from Merck Sdn. Bhd. and deionised water.

\section{Experimental Set-Up}

The aquatic plants, which were put in tap water for two weeks, were taken out; excess water was allowed to drain off and weighed. Approximately $250 \mathrm{~g}$ to $300 \mathrm{~g}$ of each aquatic plant were put into containers containing $8 \mathrm{~L}$ of copper solution at the desired concentrations. The plants were kept in the copper solution for 21 days. There were three replicates for each plant at each concentration $(1.5 \mathrm{mg} / \mathrm{L}, 2.5 \mathrm{mg} / \mathrm{L}$ and, $5.5 \mathrm{mg} / \mathrm{L})$. The plant control set-up consisted of plants which were put into containers containing water only. On the other hand, in the metal control set-up, no plants were put into the container containing copper solution at the concentrations of $1.5 \mathrm{mg} / \mathrm{L}, 2.5 \mathrm{mg} / \mathrm{L}$ and $5.5 \mathrm{mg} / \mathrm{L}$. The volume of water in each tank was kept constant and the change in volume due to evapotranspiration was compensated by the addition of deionised water.

\section{Heavy Metals Analysis}

For every 24 hours interval, $25.0 \mathrm{ml}$ of water sample were collected for heavy metal analysis. The plant samples were collected at the start and at every five-day interval of the experiment, weighed and separated into roots and shoots.
The plants were washed with deionised water, excess water was allowed to drain off and the plants were weighed. Subsequently, the plant was dried in the oven for 24 hours at $70.0^{\circ} \mathrm{C}$, for preparation to ascertain the accumulation of heavy metal of each sample. The dried plant was grounded and digested by using Nitric-Perchloric Acid Digestion method as described by USEPA, 1995 (APHA,1995). An atomic adsorption spectrometer (AAS) was used for heavy metals analyses of water and plant samples.

\section{E. Statistical Analysis}

The data were presented as mean values of three replicates. Statistical analysis using the one-way ANOVA was used to assess significant differences among the various copper concentrations. The comparisons of mean using the least significant different test were calculated for P-values. A value of $\mathrm{P}<0.01$ was considered significant. Statistical analysis software used in this research was Minitab version 15.

\section{RESUltS AND DisCUSSION}

\section{A. Copper removal from the solution}

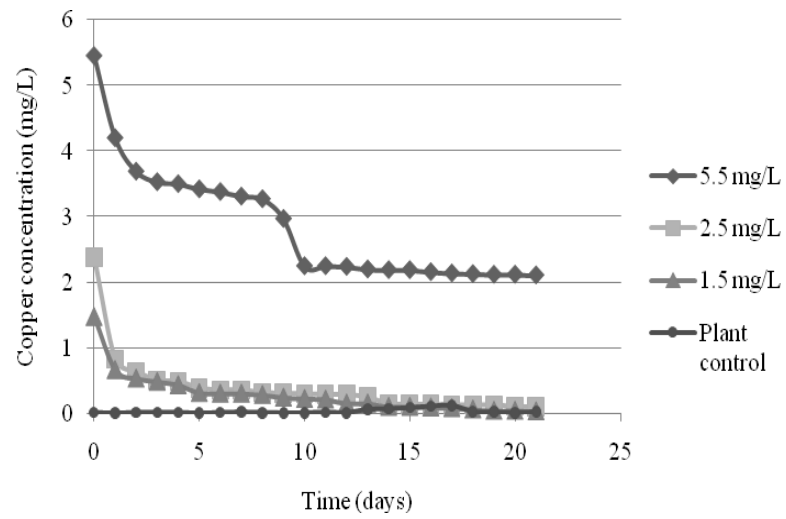

Fig. 1. Final concentration of copper in the water for Eichhornia crassipes

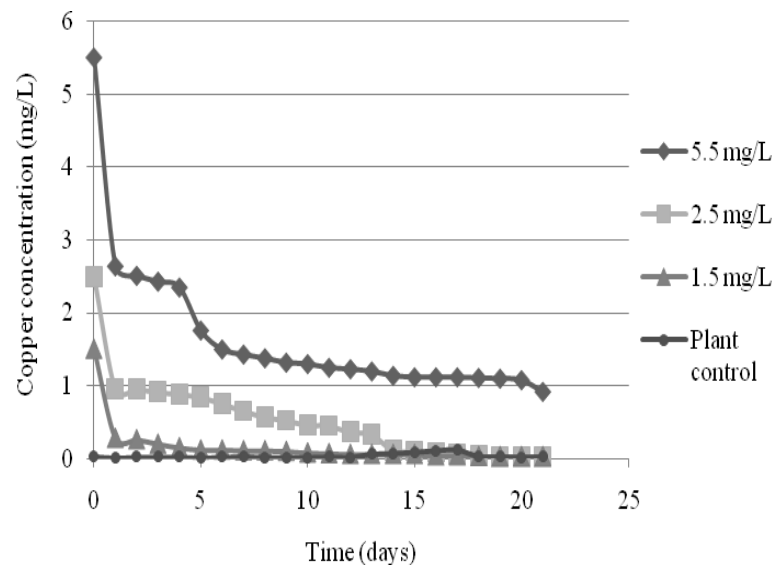

Fig. 2. Final concentration of copper in the water for Centella asiatica

Fig. 1 and Fig. 2 show the mean final concentrations of copper solutions as a function of time. The figures show that as the exposure to contaminant increases, the concentrations of copper decrease. For containers containing Eichhornia 
crassipes, the concentrations of copper decreases from 5.5 $\mathrm{mg} / \mathrm{L}$ to $2.1 \mathrm{mg} / \mathrm{L}, 2.5 \mathrm{mg} / \mathrm{L}$ to $0.11 \mathrm{mg} / \mathrm{L}$ and $1.5 \mathrm{mg} / \mathrm{L}$ to $0.04 \mathrm{mg} / \mathrm{L}$ as shown in Fig. 1. For containers containing Centella asiatica, the concentrations of copper decrease from $5.5 \mathrm{mg} / \mathrm{L}$ to $0.92 \mathrm{mg} / \mathrm{L}, 2.5 \mathrm{mg} / \mathrm{L}$ to $0.01 \mathrm{mg} / \mathrm{L}$ and $1.5 \mathrm{mg} / \mathrm{L}$ to $0.03 \mathrm{mg} / \mathrm{L}$ as in Fig 2. These results indicate that treatment using Centella asiatica is able to meet the limit of industrial effluent discharge standard for Malaysian inland waters which is $0.2 \mathrm{mg} / \mathrm{L}$ for copper for all three initial concentrations. Results obtained using both plants, Eichhornia crassipes and Centella asiatica are better compared to published results using parrot feather (Myriophylhum aquaticum), creeping primrose (Ludwigina palustris), and watermint (Mentha aquatic) for treating copper contaminated water with initial concentration of 5.56 $\mathrm{mg} / \mathrm{L}$ [5]. In the study, the copper concentration was reduced to $3.19 \mathrm{mg} / \mathrm{L}, 3.06 \mathrm{mg} / \mathrm{L}$ and $3.48 \mathrm{mg} / \mathrm{L}$ for parrot feather (Myriophylhum aquaticum), creeping primrose (Ludwigina palustris), and watermint (Mentha aquatic) respectively, after 21 days. As in [8], Lemna gibba performed extremely well in removing the zinc with an initial concentration of 6.30 $\mathrm{mg} / \mathrm{L}$. Lemna gibba thrives on contaminant and the initial zinc concentration was reduced to $1.8 \mathrm{mg} / \mathrm{L}$ within 7 days. As in Fig 1 and Fig 2, the plant control treatment consisted of no spiking of copper. It showed almost no trace of copper in the solution and plants. Thus, the initial solution and plants that was used in the study has no element of copper unless it was spiked into the solution.

Fig. 3 shows that the metal control with no plants for container containing copper solution at three different concentrations of $1.5 \mathrm{mg} / \mathrm{L}, 2.5 \mathrm{mg} / \mathrm{L}$ and $5.5 \mathrm{mg} / \mathrm{L}$. The results indicated that the concentration of copper for metal control treatment can be considered constant for 21 days.

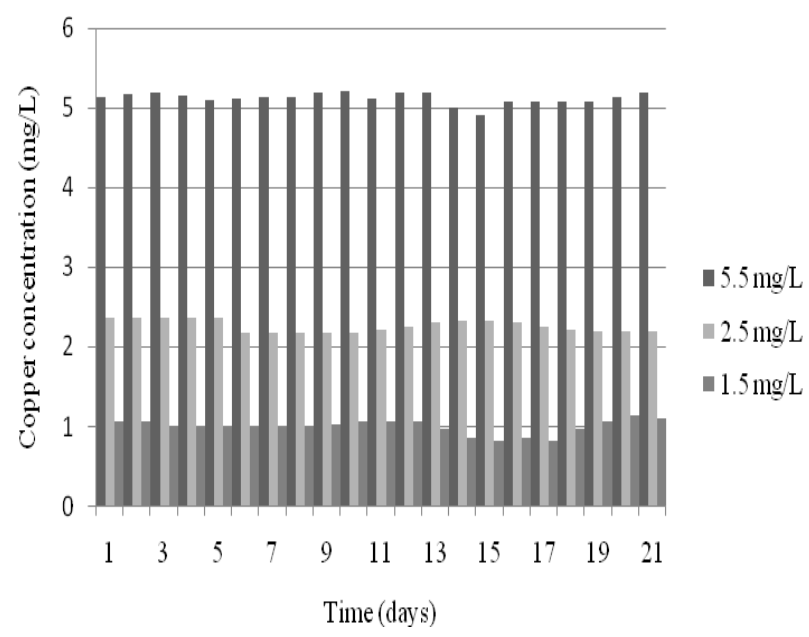

Fig. 3. Metal control treatment

\section{B. Copper removal efficiencies (\%)}

The removal efficiency, calculated as $\left(\mathrm{C}_{\mathrm{i}}-\mathrm{C}_{\mathrm{f}} / \mathrm{C}_{\mathrm{i}}\right)$ x $100 \%$ where $C_{i}$ is the initial concentration and $C_{f}$ is the remaining heavy metal concentration in the solution. Fig. 4 and Fig. 5 show the percentage removal of copper as a function of time for Eichhornia crassipes and Centella asiatica, respectively. Fig. 4 showed that Eichhornia crassipes removed $97.3 \%$ of copper at $1.5 \mathrm{mg} / \mathrm{L}, 95.6 \%$ at $2.5 \mathrm{mg} / \mathrm{L}$ and $61.6 \%$ at 5.5 $\mathrm{mg} / \mathrm{L}$ within 21 days of exposure to contaminant. As evident in Fig. 4 and Fig. 5, the highest removal is obtained within 24 hours of exposure and the percentages of copper removals for all concentrations are maximized at approximately 14 days. The occurrence is due to the decreasing capability of the plants to accumulate copper and selective sites for copper on the plant had also become saturated. Figure 4 also shows that copper removals are the highest for concentrations of 1.5 $\mathrm{mg} / \mathrm{L}$ and $2.5 \mathrm{mg} / \mathrm{L}$. This result indicates that Eichhornia crassipes is capable to remove copper at lower concentrations. Other studies have also concluded that Eichhornia crassipes are more efficient in the phytoremediation of diluted concentration of heavy metals [9]. Fig. 5 shows that Centella asiatica gives a higher copper removal, $99.6 \%$, within 21 days of exposure at concentration of $2.5 \mathrm{mg} / \mathrm{L}$. The results show that the least copper removals were at $61.4 \%$ for Eichhornia crassipes and at $83.3 \%$ for Centella asiatica for copper concentration of $5.5 \mathrm{mg} / \mathrm{L}$. This is due to the loading effect where the sorption sites were saturated by copper ions at the highest concentration. A similar trend was reported by [4], where the Pistia stratiotes and Spirodela polyrrhiza performed extremely well in removing the chromium and zinc from their solution and was capable of removing up to $92 \%$ of zinc and $83 \%$ of chromium during 12 days incubation period. Results obtained using Eichhornia crassipes and Centella asiatica are better compared to published results as in [5]. In the study, all the three plants, Myriophylhum aquaticum, Ludwigina palustris and Mentha aquatic were able to remove $41.62 \%$ of copper from contaminated water within 21 days.
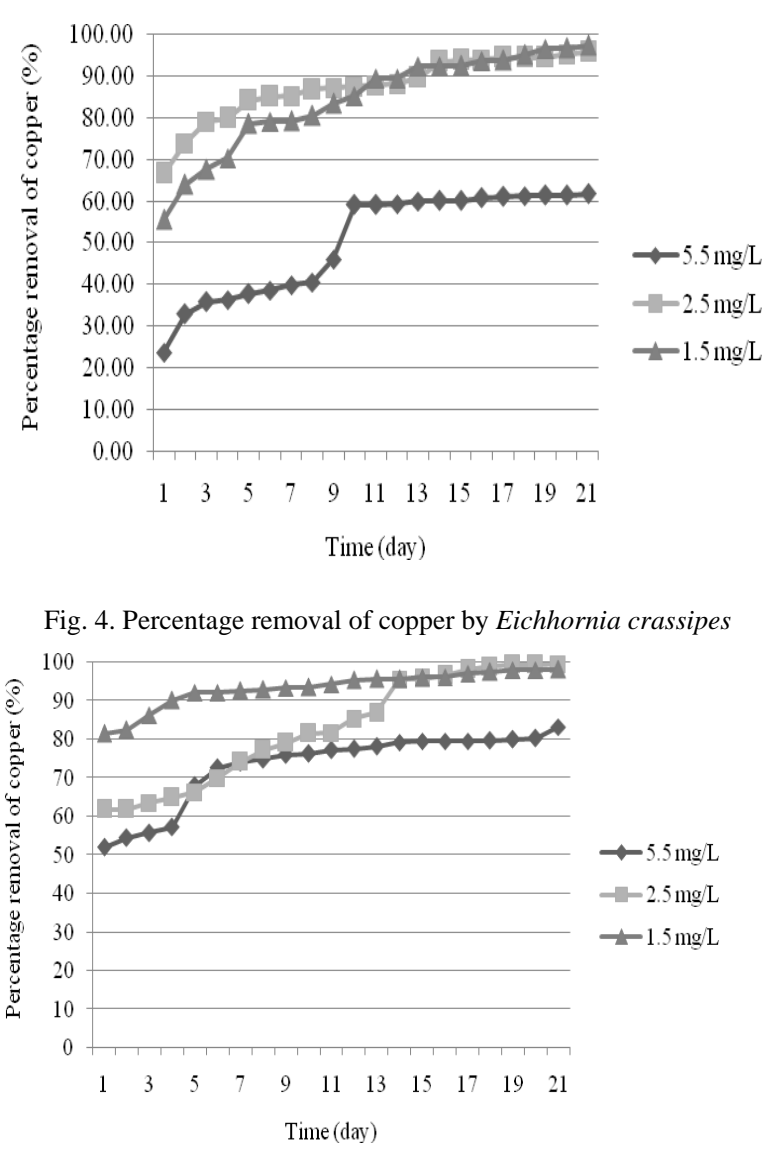

Fig. 5. Percentage removal of copper by Centella asiatica 


\section{Copper accumulation in the plant tissues}

For hyperaccumulation of heavy metals to occur, the plants must be able to accumulate more than $1000 \mathrm{mg} / \mathrm{kg}$ of the heavy metal contaminants into the plants system, either by accumulating in the roots or shoots [10]. Fig. 6 and Fig. 7 show that copper accumulation was mainly in the roots compared to the shoots. The copper accumulation in the roots of Eichhornia crassipes and Centella asiatica shows a gradual increase in the uptake of copper at increasing copper concentration of $1.5 \mathrm{mg} / \mathrm{L}$ to $5.5 \mathrm{mg} / \mathrm{L}$. For roots of Eichhornia crassipes, at copper concentration of $1.5 \mathrm{mg} / \mathrm{L}$, $2.5 \mathrm{mg} / \mathrm{L}$ and $5.5 \mathrm{mg} / \mathrm{L}$, the copper accumulation were increased to $165.0 \mathrm{mg} / \mathrm{kg}, 597.5 \mathrm{mg} / \mathrm{kg}$ and $1147.5 \mathrm{mg} / \mathrm{kg}$ respectively. The greatest accumulation of copper in Eichhornia crassipes and Centella asiatica was at copper concentration of $5.5 \mathrm{mg} / \mathrm{L}$. This indicates that at low concentration, copper accumulated by specific sites while with increasing copper concentration the specific sites are saturated and the exchange sites are filled. Centella asiatica accumulated $1353.0 \mathrm{mg} / \mathrm{kg}$ of copper contaminant and Eichhornia crassipes accumulated $1147.5 \mathrm{mg} / \mathrm{kg}$ of copper contaminant in their roots. The results indicate that Centella asiatica is considered a better copper accumulator compared to Eichhornia crassipes. Thus, Centella asiatica and Eichhornia crassipes can both be considered as hyperaccumulators since the amount of copper that can be accumulated are more than $1000 \mathrm{mg} / \mathrm{kg}$.

Table I shows that accumulation of copper for Centella asiatica was (1105.5 to $1353.0 \mathrm{mg} / \mathrm{kg}$ ) in the roots which was higher than in the shoots ( 109.5 to $122.5 \mathrm{mg} / \mathrm{kg}$ ). As copper is more localized in the aquatic plant roots, it indicates that rhizolfiltration may be the predominant mechanism for accumulation of copper [9]. Plants may accumulate higher concentration of metals in the roots since roots are usually at the base of the plant and removed from the photosynthetic process for their own tolerance [5]. This result concurs with other researchers which obtained similar results [7]. Many researchers have concluded that accumulation of metals occur mainly in the roots of plants, due to the slow mobility of metal transport from root to shoot [11]. The plants that were examined and reported to have better accumulation of metals in root portions include water hyacinth, water milfoil, and water lettuce. A similar trend was reported as in [7], where the copper analyses showed that the copper concentration in the roots of the monkey-flower and parrot feather $(450 \mathrm{mg} / \mathrm{kg}$ ) was higher than the concentrations of copper in the shoots $(40 \mathrm{mg} / \mathrm{kg})$. Water hyacinth is also suitable to take up cadmium where the highest level of cadmium found in shoots and roots were $371.0 \mathrm{mg} / \mathrm{kg}$ and $6103.0 \mathrm{mg} / \mathrm{kg}$ respectively [9]. The results showed that cadmium were more highly accumulated in roots than in shoots due to translocation process [9]. Better accumulation of heavy metals in the roots is well explained by the studies of [12]. The studies indicate that the roots absorbed metal cations via the plasma membrane involving cationic channel such as calcium and restrict their translocation to the shoots. The roots retain the cations by binding them to the cell wall. The preference to store metals in the roots system was thought to be an exclusion strategy of the plant by avoiding the toxic metals from interacting more with other plants parts [12].

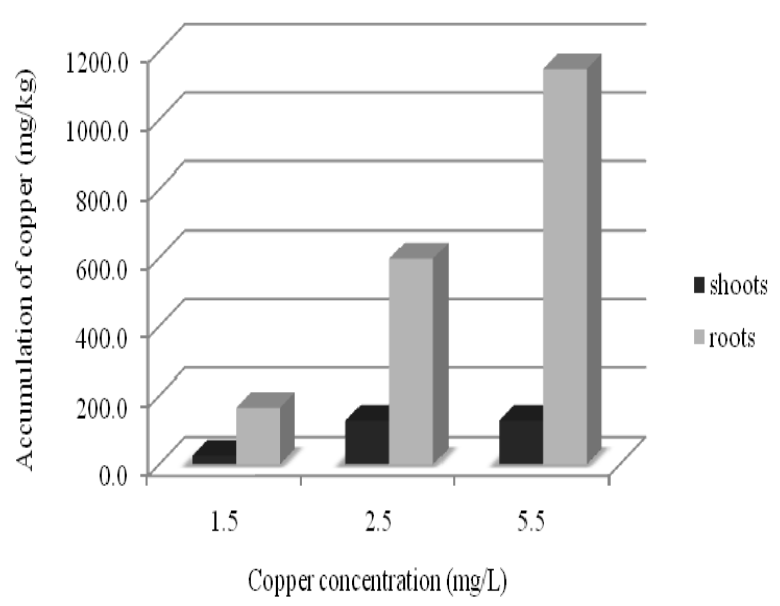

Fig. 6. Total accumulation of copper in Eichhornia crassipes

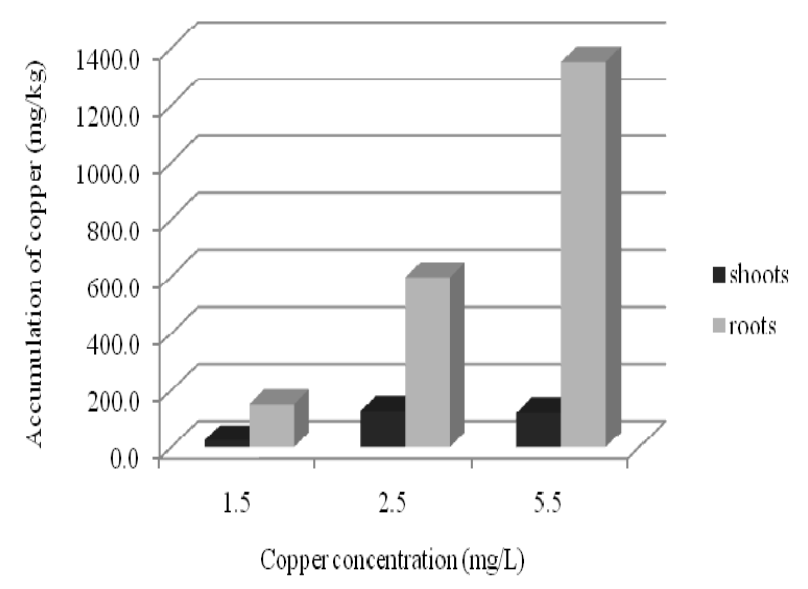

Fig. 7. Total accumulation of copper in Centella asiatica

TABLE I: THE ACCUMULATION OF COPPER IN EICHHORNIA CRASSIPES AND CENTELLA ASIATICA

\begin{tabular}{|c|c|c|c|c|c|c|}
\hline \multirow{3}{*}{$\begin{array}{l}\text { Exposure } \\
\text { time (days) } \\
\text { Eichhornia } \\
\text { crassipes }\end{array}$} & \multicolumn{6}{|c|}{ Accumulation of $\mathrm{Cu}(\mathrm{mg} / \mathrm{kg})$} \\
\hline & \multicolumn{2}{|c|}{$1.5 \mathrm{mg} / \mathrm{L}$} & \multicolumn{2}{|c|}{$2.5 \mathrm{mg} / \mathrm{L}$} & \multicolumn{2}{|c|}{$5.5 \mathrm{mg} / \mathrm{L}$} \\
\hline & $\begin{array}{c}\text { Shoot } \\
\text { s }\end{array}$ & Roots & $\begin{array}{c}\text { Shoot } \\
\mathrm{s}\end{array}$ & Roots & $\begin{array}{c}\text { Shoot } \\
\mathrm{s}\end{array}$ & Roots \\
\hline 5 & 19.5 & 87.5 & 121.5 & 477.5 & 115.5 & 997.5 \\
\hline 10 & 21.5 & 90.0 & 124.5 & 532.5 & 119.5 & 1085.0 \\
\hline 15 & 21.0 & 130.0 & 125.5 & 575.0 & 121.0 & 1130.0 \\
\hline 20 & 25.0 & 165.0 & 127.5 & 597.5 & 127.5 & 1147.5 \\
\hline $\begin{array}{l}\text { Centella } \\
\text { asiatica }\end{array}$ & $\begin{array}{c}\text { Shoot } \\
\text { s }\end{array}$ & Roots & $\begin{array}{c}\text { Shoot } \\
\mathrm{s}\end{array}$ & Roots & $\begin{array}{c}\text { Shoot } \\
\mathrm{s}\end{array}$ & Roots \\
\hline 5 & 19.0 & 85.0 & 110.5 & 490.0 & 109.5 & 1105.0 \\
\hline 10 & 21.5 & 97.5 & 113.5 & 530.0 & 111.5 & 1168.0 \\
\hline 15 & 23.5 & 135.0 & 125.5 & 575.0 & 120.0 & 13230 \\
\hline 20 & 25.0 & 150.0 & 127.0 & 597.0 & 122.5 & 1353.0 \\
\hline
\end{tabular}

\section{Plant growth assessment}

In this study, the growth of the plants was assessed by monitoring the wet weight of the plants at the start and at every five-day intervals of the experiment. The relative growth of the plants was calculated as $\mathrm{W}_{\mathrm{f}} / \mathrm{W}_{\mathrm{i}}$ where $\mathrm{W}_{\mathrm{f}}$ is the final wet weight of plants after exposure to contaminant and 
$\mathrm{W} i$ is the initial weight of the plants [13]. Table II shows an increase of wet weight for Centella asiatica and Eichhornia crassipes after exposure to contaminant. For Eichhornia crassipes, the wet weight increased from $279.4 \mathrm{~g}$ to $441.9 \mathrm{~g}$ whereas the wet weight of Centella asiatica increased from $281.5 \mathrm{~g}$ to $507.0 \mathrm{~g}$ at copper contaminant of $2.5 \mathrm{mg} / \mathrm{L}$. This result indicates that concentration of copper contaminant did not significantly affect the growth of Centella asiatica and Eichhornia crassipes. In fact, both plants seemed healthy and produced new shoots. The growth of Centella asiatica was higher than the growth of Eichhornia crassipes based on their increased wet weights. This result suggests that Centella asiatica are able to grow better at longer exposure duration compared to Eichhornia crassipes. The effects of copper on the relative growth of Eichhornia crassipes and Centella asiatica at different concentrations and exposure times are shown in Fig. 8 and Fig. 9. The relative growth of aquatic plants exposed to copper at every concentration decreased from those of plant controls. At high metal concentrations, $5.5 \mathrm{mg} / \mathrm{L}$, the relative growth of both aquatic plants was reduced after 10 days. Since, the relative growth of all plants were close to 1 , both plants show potential to be used in the phytoremediation system which requires plants to be able to accumulate acceptable amount of metals and also survive in the contaminated condition [13].

TABLE II: Wet Weight Of Plants Before And After Exposure To CONTAMINANT

\begin{tabular}{ccccc}
\hline \hline $\begin{array}{c}\text { Exposure time } \\
\text { (days) }\end{array}$ & \multicolumn{4}{c}{ Wet Weight of plants (g) } \\
\hline $\begin{array}{c}\text { Eichhornia } \\
\text { crassipes }\end{array}$ & Plant control & $1.5 \mathrm{mg} / \mathrm{L}$ & $2.5 \mathrm{mg} / \mathrm{L}$ & $5.5 \mathrm{mg} / \mathrm{L}$ \\
0 & 286.0 & 285.6 & 279.4 & 291.0 \\
5 & 356.0 & 346.1 & 306.5 & 307.0 \\
10 & 425.1 & 398.7 & 327.1 & 371.9 \\
15 & 528.0 & 509.1 & 379.8 & 407.2 \\
20 & 701.0 & 698.7 & 441.9 & 431.5 \\
$\begin{array}{c}\text { Centella } \\
\text { asiatica }\end{array}$ & Plant control & $1.5 \mathrm{mg} / \mathrm{L}$ & $2.5 \mathrm{mg} / \mathrm{L}$ & $5.5 \mathrm{mg} / \mathrm{L}$ \\
0 & 285.0 & 289.7 & 281.5 & 287.6 \\
5 & 297.1 & 279.1 & 280.4 & 278.2 \\
10 & 342.0 & 351.4 & 349.6 & 309.5 \\
15 & 491.8 & 444.7 & 407.5 & 365.1 \\
20 & 726.0 & 571.6 & 507.0 & 436.0 \\
\hline \hline
\end{tabular}

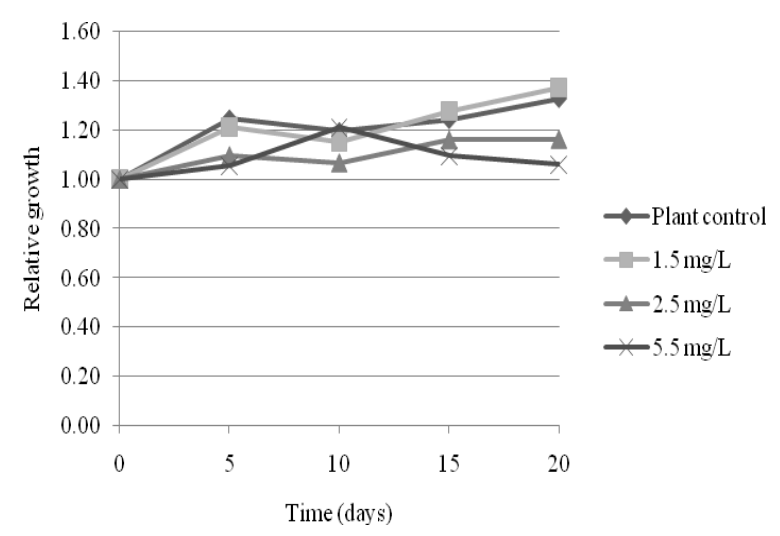

Fig. 8. Relative growth of Eichhornia crassipes

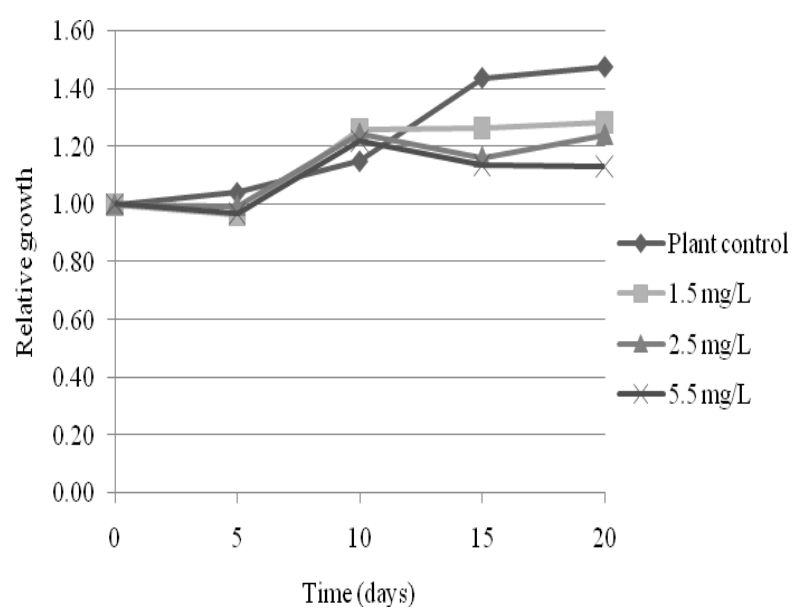

Fig. 9. Relative growth of Centella asiatica

\section{E. Statistical Analysis}

The analysis of variance (ANOVA) test done for the differences in the removal percentage of heavy metals between experiment (with plants) and control (without plants) and between different heavy metals concentration. Table II shows that the experiment (with plants) has significant removal percentage of copper in comparison with control (without plants) in terms of copper removal by aquatic plants, Eichhornia crassipes and Centella asiatica $(\mathrm{p}<0.001)$. The removal efficiency between different concentration for both aquatic plants was proved to be statistically significant $(\mathrm{p}<0.01)$ for Eichhornia crassipes and Centella asiatica respectively.

TABLE III: ANOVA TABle Showing The Performance OF Plants IN TERM OF PERCENTAge REMOVAL OF COPPER

\begin{tabular}{|c|c|c|c|c|c|}
\hline $\begin{array}{l}\text { Source of } \\
\text { variance }\end{array}$ & $\mathrm{df}$ & SS & MS & $\mathrm{F}$ & $\mathrm{P}$ \\
\hline \multicolumn{6}{|l|}{$\begin{array}{l}\text { Eichhornia } \\
\text { crassipes }\end{array}$} \\
\hline Total SS & 23 & 9593.2 & - & - & - \\
\hline Between & & & & & \\
\hline $\begin{array}{l}\text { different } \\
\text { concentration }\end{array}$ & 2 & 3191.4 & 1595.7 & 21.78 & $<0.01$ \\
\hline $\begin{array}{l}\text { Between } \\
\text { experimental } \\
\text { and control }\end{array}$ & 1 & 5284.7 & 5284.7 & 94.60 & $<0.001$ \\
\hline Error & 20 & 1118.0 & 55.9 & - & - \\
\hline \multicolumn{6}{|l|}{$\begin{array}{l}\text { Centella } \\
\text { asiatica }\end{array}$} \\
\hline $\begin{array}{l}\text { Total SS } \\
\text { Between }\end{array}$ & 23 & 7785.2 & - & - & - \\
\hline $\begin{array}{l}\text { different } \\
\text { concentration }\end{array}$ & 2 & 728.1 & 364.0 & 4.08 & $<0.01$ \\
\hline $\begin{array}{l}\text { Between } \\
\text { experimental } \\
\text { and control }\end{array}$ & 1 & 6035.2 & 6035.2 & 118.21 & $<0.001$ \\
\hline Error & 20 & 1022.0 & 51.1 & - & - \\
\hline
\end{tabular}




\section{CONCLUSIONS}

In this study, the effectiveness of two aquatic plants, Centella asiatica and Eichhornia crassipes, in removing copper from copper solutions were investigated. Results obtained indicated that both plants were very effective in removing copper. These plants were able to remove the heavy metal successfully without any physical signs of being affected by it. The highest percentages of removal of copper was $99.6 \%$ for Centella asiatica and $97.3 \%$ for Eichhornia crassipes, were obtained at concentrations of copper solution of $2.5 \mathrm{mg} / \mathrm{L}$ and $1.5 \mathrm{mg} / \mathrm{L}$ respectively Centella asiatica, a less studied plant in the field of phytoremediation, shows higher accumulation of copper in its roots compared to Eichhornia crassipes. Overall results indicate that both, Centella asiatica and Eichhornia crassipes can be used for phytoremediation of copper contamination in water.

\section{ACKNOWLEDGMENT}

The author would like to thank the School of Industrial Technology for providing the research facilities, and the laboratory technicians for providing technical assistance.

\section{REFERENCES}

[1] M. Ghosh, and S. P. Singh, "A review on phytoremediation of heavy metals and utilization of its byproducts," Applied ecology and environmental research, vol. 3, no. 1, pp.1-18, June 2005.

[2] P.K. Rai, "Heavy Metal Phytoremediation from Aquatic Ecosystems with Special Reference to Macrophytes," Critical Reviews in Environmental Science and Technology, vol. 39, no. 9, pp. 697-753, September 2009.

[3] Manuela, D. Machado, Helena, M. V. M. Soares and Eduardo V. Soares, "Removal of Chromium, Copper, and Nickel from an Electroplating Effluent Using a Flocculent Brewer's Yeast Strain of Saccharomyces cerevisiae, ” Water Air Soil Pollution, vol. 212, pp. 199-204, February 2010.

[4] V. K. Mishra, and B. D. Tripathi, "Concurrent removal and accumulation of heavy metals by three aquatic macrophytes," Bioresource Technology, vol. 99, pp. 7091-7097, January 2008.

[5] M. Kamal, A. E. Ghaly, N. Mahmoud, and R. Cote, "Phytoaccumulation of heavy metals by aquatic plants," Environmental International, vol. 29, pp. 1029-1039, March 2003.

[6] T. P. Choo, C. K. Lee, K. S. Low, and O. Hishamuddin, “Accumulation of Chromium (VI) from aqueous solutions using water lilies (Nymphaea spontanea),” Chemosphere, vol. 62, pp. 961-967, May 2005.

[7] J. H. Qian, A. Zayed, Y. L. Zhu, MeiYu and N. Terry, "Phytoaccumulation of trace elements by wetland plants: III. Uptake and accumulate of ten trace elements by twelve plant species,” $J$. Environ. Qual., vol. 28, no. 5, pp 1448-1456, 1999.
[8] K. Nabila, and Z. Mostefa, "Phytoaccumulation of zinc by the aquatic plant Lemna gibba L.” Bioresource Technology, vol. 100, pp. 6137-6140, June 2009.

[9] Y. L. Zhu, A. M. Zayed, J. H. Qian, M. De Souza and N. Terry, "Phytoaccumulation of Trace Elements by Wetland Plants: II. Water Hyacinth,” Journal of Environmental Quality, vol. 28, no. 1, pp 339-344, 1999.

[10] A. J. M. Baker, and R. R. Brooks, "Terrestrial higher plants which hyperaccumulate metallic elements-A review of their distribution, ecology and phytochemistry,” Biorecovery, vol. 1, no. 2, pp81-126, 1989.

[11] P. Chandra, and K. Kulshreshtha, "Chromium accumulation and toxicity in aquatic vascular plants,” Botan. Rev., vol. 70, no. 3, pp. 313-327, October 2004.

[12] K. Skinner, N. Wright, and E. Porter-Goff, "Mercury uptake and accumulation by four species of aquatic plants," Environmental pollution, vol. 145, pp 234-237, March 2006.

[13] C. Lamai, M. Kruatrachue, P. Pokethitiyook, E. S. Upatham and V. Soonthornsarathool, "Toxicity and accumulation of lead and cadmium in the filamentous green alga Cladophora fracta: A laboratory study,” ScienceAsia, vol. 31, pp. 121-127, February 2005.

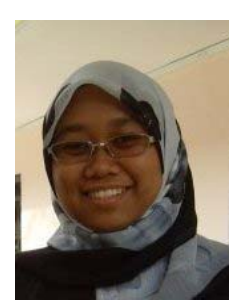

H. Mokhtar obtained her BSc in Environmental Technology from Universiti Teknologi Mara, Shah Alam, Malaysia in 2009.

Currently, she is an MSc research student at the School of Industrial Technology, Universiti Sains Malaysia, Penang. She also holds a fellowship from the Institute of Postgraduate Studies, Universiti Sains Malaysia.

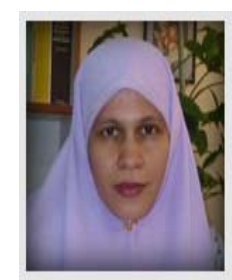

N. Morad obtained her BSc in Chemical Engineering from the University of Missouri - Columbia, USA, in 1985 and her PhD in Control Engineering, University of Sheffield, United Kingdom, 1997

Her areas of research include development of Intelligent Systems, life cycle assessment (LCA), and development of new methods and materials in biological and chemical wastewater treatment.

Associate Professor Morad is currently the Chairperson of the Environmental Technology Division, School of Industrial Technology, Universiti Sains Malaysia.

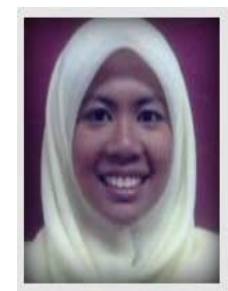

F.F. Ahmad Fizri obtained her BSc in Biotechnology from the Universiti Sains Malaysia in 2001 and her MSc in Environmental Management from Universiti Kebangsaan Malaysia in 2004. Currently, she is a lecturer at School of Industrial Technology, Universiti Sains Malaysia. She is also a fellow at the Centre for Global Sustainability Studies in Universiti Sains Malaysia. Her main interest is in Occupational Safety and Health. 